\title{
Plant secretions prevent wasp parasitism in nests of wool-carder bees, with implications for the diversification of nesting materials in Megachilidae
}

\author{
Thomas Eltz $^{1 *}$, Jennifer Küttner ${ }^{1}$, Klaus Lunau ${ }^{2}$ and Ralph Tollrian ${ }^{1}$ \\ ${ }^{1}$ Department of Animal Ecology, Evolution and Biodiversity, Ruhr University Bochum, Bochum, Germany \\ 2 Institute of Sensory Ecology, Heinrich-Heine-Universität, Düsseldorf, Germany
}

Edited by:

Florian Paul Schiestl, University of

Zürich, Switzerland

Reviewed by:

Thomas Schmitt, University of

Wuerzburg, Germany

Stefan Dötterl, University of

Salzburg, Austria

Nicolas Jean Vereecken, Université

Libre de Bruxelles, Belgium

Johannes Stökl, University of

Regensburg, Germany

*Correspondence:

Thomas Eltz, Department of Animal Ecology, Evolution and Biodiversity,

Ruhr University Bochum,

Universitätsstr. 150, NDEF 05/788,

44780 Bochum, Germany

e-mail:thomas.eltz@

ruhr-uni-bochum.de
Bees make use of plant substrates in more ways than any other group of insects, which is probably linked to their diversification and ecological success. The highly diverse Megachilidae use a wide range of plant-derived brood cell-building materials, including plant leaves, mortar made from plant tissue, resin, plant hairs ("plant wool"), and plant trichome secretions. While certain plant-derived materials are believed to protect nests against microbial decay, this has not been tested, and the factors driving diversification of nesting materials are poorly understood. Here, we investigated the protective effects of plant-derived extrafloral trichome secretions which female European wool-carder bees, Anthidium manicatum, smear on their brood cells. By breeding bees in cages with differential resource supply we generated brood cells with or without trichome secretions. Brood cells with trichome secretions were less attractive to chalcidoid wasps (Monodontomerus obscurus), potential parasites of $A$. manicatum, in Y-maze olfactometer tests. Also, when exposed at sites where $A$. manicatum occurs in natural populations, brood cells smeared with trichome secretions were less affected by wasp (Melittobia acasta) parasitism than those without trichome secretions. On the other hand, trichome secretions did not prevent the growth of mold on brood cells, and larval mortality due to microbial decay was almost non-existent even when brood cells were exposed to rainfall. We conclude that the use of plant trichome secretion for brood cell construction has more likely evolved to create enemy-free space in response to chalcidoid wasp parasitism. Parasitoids are likely an underestimated cause of the diversification of cell construction materials and adaptive radiation in megachilid bees.

Keywords: parasitoid, Anthidium, megachilid, extrafloral trichomes, nesting biology, insect-plant interactions

\section{INTRODUCTION}

The radiation and ecological success of bees (Hymenoptera: Apiformes) has been linked to their shift from a primarily carnivorous diet of small arthropod prey to a herbivorous diet of pollen and nectar, which are the bees main larval food and source of energy (Grimaldi, 1999; Dötterl and Vereecken, 2010; Cardinal and Danforth, 2013). However, besides their obvious importance as food, plant substrates or plant-derived compounds are used by bees also for nest-building (Westrich, 1989; Cane et al., 2007), defense (Duangphakdee et al., 2009), and sexual communication (Eltz et al., 2005). Especially with regard to nest building, the use of plant materials is extremely diverse, often highly specialized, and has been linked to the diversification of certain bee groups, e.g., the family Megachilidae (Litman et al., 2011). The non-parasitic members of this family are solitary bees that, typical for aculeate (stinging) Hymenoptera, store larval food provisions in "brood cells." In most species of Megachilidae these brood cells are not excavated in the soil, but are built from various materials in pre-existing cavities above ground or attached as self-constructed envelopes to vegetation or inanimate objects.
The materials that are used for building brood cells range from mud and little stones to a wide range of plant-derived substrates such as resin, pulp made from leaf material, entire pieces of leafs, and plant hairs (Westrich, 1989; and citations in Litman et al., 2011). It has been demonstrated that some of the plant-derived material is hydrophobic (Messer, 1985; Müller et al., 1996), thus potentially serving an anti-microbial function similar to that of the Dufour-gland secretions that many soil nesting bees use to impregnate their brood cells (Cane, 1981; Hefetz, 1987; Mitra, 2013). Alternatively, the staggering range of different foreign materials may reflect differential selective pressures from predators or parasitoids, or at least constitute differential solutions of countermeasures against the attacks of predators or parasitoids. However, experimental evidence is lacking or scarce (Messer, 1985) to support either functional hypothesis, and the evolution and diversification of nest building materials in Megachilidae remains enigmatic.

In the present study we investigated the protective function of one particular plant substrate, plant extrafloral trichome secretions, in nest building. Such secretions are smeared on brood cells 
by females of the European Wool Carder Bee, Anthidium manicatum (Megachilidae: Anthidiinae) (Müller et al., 1996), as well as by females of $\sim 90$ other species of wool-carder bees worldwide (Gonzalez and Griswold, 2013). The prime building material of wool-carder bee brood cells are plant hairs ("wool") which are collected from stems and leafs of certain plants (Westrich, 1989). A. manicatum uses predominatly hairs of Lamiaceae, especially species of Stachys and Betonica, which are formed into spheres within pre-existing cavities in wood or rock crevices (Müller et al., 1996). In addition female wool-carder bees use special hair structures on the exterior surface of their tarsi (so-called "tomenta") to absorb the secretion protruding from extrafloral trichomes (plant hairs) of a completely different set of plant species, and apply these secretions on the wool cells (Müller et al., 1996; Gonzalez and Griswold, 2013), see Figure 1. In A. manicatum, sources for trichome secretions include species of Anthirrinum, Crepis, and Pelargonium. There is only sketchy information about the function that the secretions have in the plants, but in Pelargonium it has been shown to mediate protection against phytophagous arthropods (Walters et al., 1989; Schultz et al., 2006). Nothing is known about its function in the nesting biology of Anthidium except for the notion that plant wool soaked with trichome secretion is water repellent (Müller et al., 1996). Our study was initiated by the observation that caged female A. manicatum are able to build brood cells both with or without a coating of trichome secretions, depending on whether they had access to source plants (Lampert et al., 2014; Pasternak and Eltz, pers. obs.). Using cells from populations of cage-breeding bees we tested whether coated cells have an advantage over uncoated cells by being (1) olfactorily less attractive to parasitoid wasps in dual choice laboratory experiments, (2) less susceptible to parasitoid-induced mortality when exposed in the field, and (3) less susceptible to mold and mold-induced mortality when exposed in the field.

\section{MATERIALS AND METHODS \\ ANTHIDIUM MANICATUM BROOD CELLS}

Four mesh-covered flight cages of $4 \times 2 \times 2 \mathrm{~m}$ (custom-made, frame of aluminum tubing) were installed in the Botanical Garden of the Ruhr-University Bochum in the summer of 2013. All cages contained two rows of freely planted Betonica officinalis (for pollen and nectar), potted plants of Stachys byzantina (for plant "wool," the prime material of A. manicatum brood cells), and trap-nests in the form of split bamboo canes (length 9-27 cm, inner diameter $1.2-2.2 \mathrm{~cm}$ ) fixed to wooden poles and sheltered from rain. Additionally, two of the four cages contained potted plants of Pelargonium $\times$ zonale which females used as sources of trichome secretions. We offered Pelargonium as a source plant because it was available and flowering throughout the entire field season, and because of the quantity of trichome secretions it offers. It is not native to the study area but highly attractive to A. manicatum females. Wild female (four per cage) and male (two per cage) A. manicatum were captured at their food plants in the Botanical Gardens of Bochum and Düsseldorf, marked individually with dots of acrylic paint on the mesosoma, and introduced into these cages. They habituated quickly to the new situation, with males engaging in territorial behavior around the food plants, and females provisioning brood cells as linear nests in the bamboo internodes (see Lampert et al., 2014). Females in the respective cages were regularly observed to collect trichome secretions from flower petioles and buds of Pelargonium, and reddish coatings were visible with the bare eye on $\sim 70 \%$ of brood cells (Figure 1). Bamboo internodes with completed nests were removed upon completion. Twenty-four separate nests with a

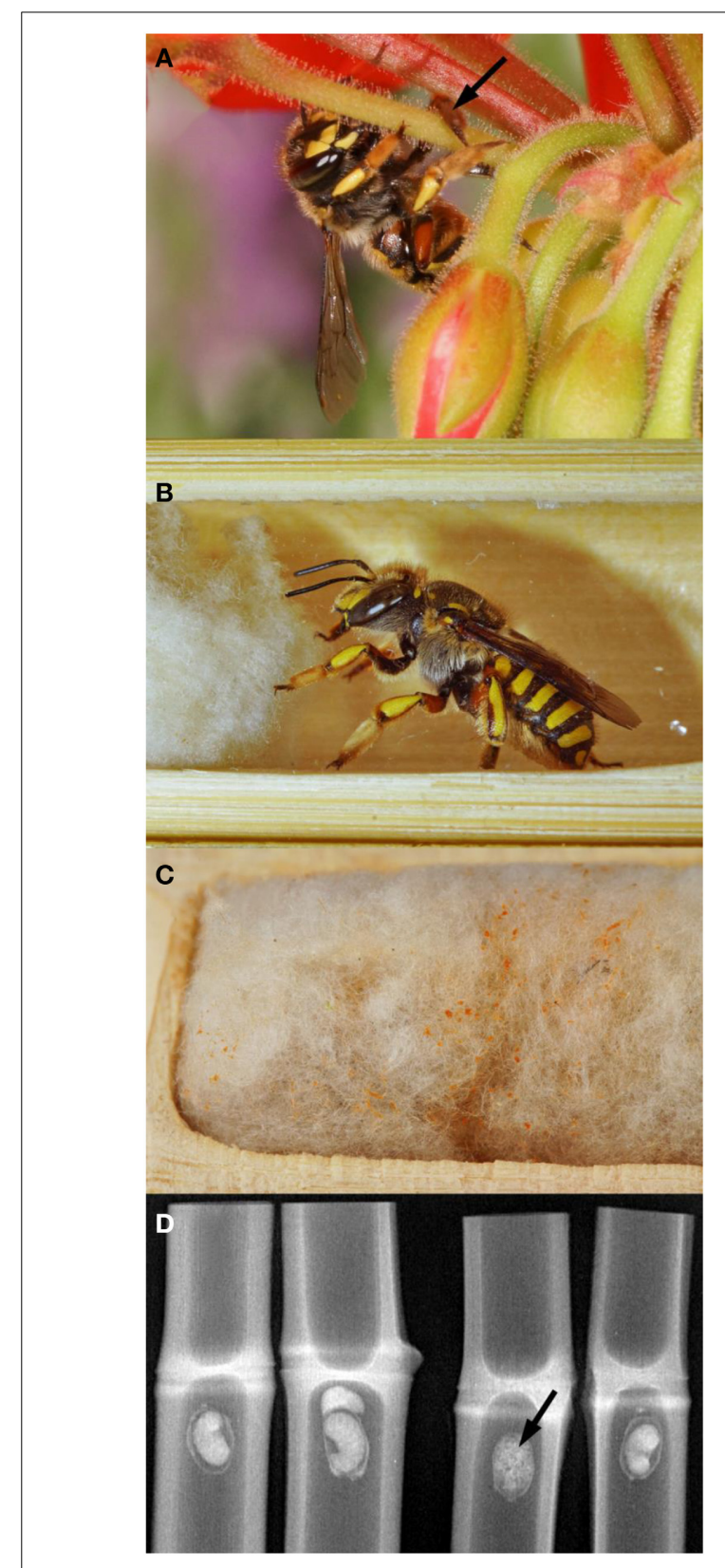

FIGURE 1 | (A) Female Anthidium manicatum collecting secretions from trichomes on Pelargonium flower petioles in a flight cage using specialized hairs on tarsi (arrow). (B) Female returning to uncoated brood cell made of plant hairs (wool) in a bamboo internode. (C) Wooly brood cell coated with Pelargonium secretions visible as orange spots. (D) X-ray scans of brood cells taken during the exposure experiment. Three cells contain healthy larvae (prepupae), but one (arrow) was found to be parasitized by Melittobia wasps when dissected at the end of the experiment. 
total of 143 brood cells were built by the females in the cages with Pelargonium, and 21 nests with 140 cells in those without. All females actively provisioned nests and therefore contributed some brood cells, but the exact number of cells that an individual female contributed is unknown because we did not continuously monitor female/nest associations. It should be noted that trichome secretions are not necessary for the construction of brood cells per se. Cells without secretions do not obviously differ in size or shape from those with secretions, and we know from previous years that brood can develop normally in secretion-free cells (Eltz, unpublished). Consequently, the trichome secretions are not essential for putting together or for maintaining the shape of a brood cell.

\section{PARASITIC WASPS AND OLFACTOMETER TESTS}

We tested female chalcidoid waps, Monodontomerus obscurus (Torymidae), for olfactory-mediated preferences with regard to the presence or absence of Pelargonium trichome secretions (see below) on brood cells. M. obscurus is a generalist parasitoid of megachilids and can be raised from cells of managed mason bees (Osmia spp.) and leaf-cutter bees (Megachile spp.) (Rank and Goerzen, 1981; Krunic et al., 2005; Fliszkiewicz et al., 2012). A. manicatum has not been recorded as a host in the literature available to us (its nests are rarely found), but it is likely to be parasitized when accessible. As the results of the field exposure experiments (Melittobia acsta attacks, see below) were not yet available to us at the time of the olfactometer tests, we used $M$. obscurus for reasons of practicality and the close relatedness of its known hosts to A. manicatum. A closely related species, Monodontomerus aeneus, is known to respond positively to odorants emanating from mason bee brood cells (Filella et al., 2011). Our experimental M. obscurus were raised from overdue cocoons of the red mason bee, Osmia bicornis, obtained from M. Herrmann, Konstanz. Cocoons were kept in the fridge until mid August 2013, consecutively, and depending on experimental demand, we placed small numbers in plastic containers at room temperature. Adult wasps emerged after 8-14 days, and females were tested 1-8 days after emergence.

A Y-type olfactometer (see Supplementary Material) was used in behavioral tests: air was blown into the inlet at $150 \mathrm{ml} / \mathrm{min}$ using an aquarium pump. The current was divided into two equal volumes using a PVC T-connector and two short pieces of silicone tubing $(10.5 \times 0.8 \mathrm{~cm})$ that each connected to a glass chamber for stimulus substances $(10.5 \times 2.1 \mathrm{~cm})$. From the glass chambers air laden with stimulus or control odors was led on to join in a glass $y$-connector $(0.6 \mathrm{~cm}$ diameter $)$, where wasps were placed to make their choice. Downwind from the glass chambers all parts were rinsed with acetone (y-connector) or replaced (silicone tubing) after each trial. Wasps and brood cells were only tested once, and we swapped left and right positions of stimulus/control after each test to avoid bias.

We presented the wasps with the following choices $(n=50$ each): brood cell coated with Pelargonium-secretions vs. uncoated brood cell (dual choice), either type of brood cell vs. an empty glass chamber, and raw trichome secretions in the form of Pelargonium buds (2-5 buds, depending on size) vs. an empty glass chamber. A choice was recorded as soon as a wasp had spent at least 10 s continuously in one branch of the $y$-connector. If that had not happened after 3 min the wasp was removed and recorded as undecided.

We tested the null hypothesis that the number of decisions made for either branch of the y-olfactometer was uniformly distributed using a Goodness-of-fit $X^{2}$-Test.

\section{FIELD EXPOSURE OF BROOD CELLS}

To test whether Pelargonium secretions convey a survival advantage to bee brood in the field we exposed 65 units of brood cells at various locations in suburban Bochum and Düsseldorf. Exposure period was slightly variable between units and began between early August and early September 2013 and ended between the end of December 2013 and early January 2014 (averaging $\sim 4$ months). Two bamboo canes were used per unit, and each cane was split in half. The two canes of a unit were held together by a screw and two pieces of gray PVC $(12 \times 3 \mathrm{~cm}$; see Supplementary Material), and one coated and one uncoated brood cell was placed singly at the rear of its bamboo cane. Fourty-two of the units were placed within the shelves of existing artificial trap-nest aggregations (bee "hotels"), increasing the chances that bee predators or parasitoids would find the brood cells, but also providing some protection against wind and rainfall. The other 23 units were fixed to poles, fences or tree stems in the vicinity of trap-nest aggregations (1-3 $\mathrm{m}$ away), but without protection against rainfall. This treatment was supposed to promote moistening and, consecutively, mold infection of brood cells.

Brood cells were monitored during the exposure period in two ways. Bamboo canes were opened regularly (every week during the first 6 weeks, later every 3 weeks) and standardized pictures of brood cells were taken with a digital camera (Casio Exilim Pro Ex-F1). Parasitoid wasps present in the internodes were collected with forceps and stored in $70 \% \mathrm{EtOH}$. Signs of parasitism such as holes in the wall of brood cells were noted and the degree of mold present on bamboo and/or brood cell was scored ( 0 : no visible mold; 1 : mold on bamboo but not on brood cell; 2: small spots of mold on brood cell wool; 3: mold distributed over brood cell; 4: mold covers most of brood cell, wool hardened, 5: brood cell grown over by sticky mold, volume of wool reduced). Additionally, all bamboo internodes were $\mathrm{x}$-rayed three times (once before exposure, once 6 weeks after exposure, and once at the end of the exposure period) to reveal hidden mortality or concealed parasitism. X-ray scans were made by the staff of the Radiology department of the Knappschafts-Krankenhaus Bochum using a Siemens Multix xray scanner at $55 \mathrm{kV} / 4 \mathrm{mAs}$. By the end of the exposure all brood cells that did not clearly contain a healthy A. manicatum prepupa were dissected to elucidate causes of mortality (see Figure 1). Generally, mortality may have been underestimated as the experiment stopped in winter and did not last until hatching of adults.

The effects of the factors (a) shelter and (b) coating with trichome secretion on the degree of mold infection was tested with a Two-Way Univariate PERMANOVA using the software PAST 3.04 (Euclidean Distances, 9999 permutations; Hammer et al., 2001). We used One-Way PERMANOVA in the same software to test for effects of shelter separately. For testing differences in the 
frequency of parasitoid-induced mortality in sheltered vs. unsheltered and coated vs. uncoated brood cells we used Fishers Exact Test in the software Instat (Graphpad).

\section{RESULTS}

\section{WASP OLFACTORY PREFERENCES}

The majority $(87.5 \%)$ of female $M$. obscurus made a clear choice within the first $3 \mathrm{~min}$ of the dual choice (y-maze) olfactometer tests. The remaining undecided cases were removed from the analysis, resulting in sample sizes slightly below $N=50$ in the four different comparisons (Figure 2). Wasps significantly preferred both uncoated and coated brood cells over an empty stimulus chamber (Uncoated: $N=45, X^{2}=16.20, p<0.0001$; Coated: $\left.N=44, X^{2}=5.81, p<0.05\right)$. However, when uncoated and coated cells were tested against each other, wasps clearly preferred the uncoated variant $\left(N=41, X^{2}=12.90, p<0.0001\right)$. Samples of Pelargonium buds and petioles tended to be avoided by the wasps in comparison to an empty stimulus chamber, but this difference was only marginally significant $\left(N=45, X^{2}=3.76\right.$, $p=0.053)$.

\section{MOLD AND PARASITOIDS IN THE FIELD}

Of the 65 replicate units of brood cells that were exposed 10 were lost partly or completely during the exposure period, reducing the sample size for the various analyses.

There was a signifikant difference in mold cover depending on whether bamboo internodes were sheltered from rainfall or not (Two-Way PERMANOVA, $N=110, F=230.21, d f=$ $1, p<0.0001$; Figure 3A). In sheltered internodes some mold was always present but mostly confined to the bamboo walls (Median cover category 1). In unsheltered internodes mold was regularly present on the brood cell as well (Median cover category 3). Across all units, there was no significant difference in mold cover between the cells coated with trichome secretions and the uncoated cells $(N=110, F=1.11, d f=1, p=$ $0.25)$. There was however a significant interaction between the factors "shelter" and "coating" on mold growth $(N=110, F=$ $16.86, d f=1, p<0.001)$, suggesting that coated cells were even more affected by mold in unsheltered conditions (Figure 3A). The significant interaction term in the absence of a significant main effect of coating may have resulted from the fact that the only two cells in the highest mold category (5; only occurring in unsheltered sites) were coated. We therefore tested whether the significance of the shelter effect would hold if coated and uncoated cells were tested separately, and this was the case for both subsets (One-Way PERMANOVA, coated cells: $N=55, F=$ 120.9, $d f=1, p<0.0001$; uncoated cells: $N=55, F=83.75$, $d f=1, p<0.0001)$. In any case, coating with trichome secretions did clearly not inhibit mold growth. Notably, even very severe growth of mold (categories 4 and 5) did not lead to mortality of the brood in the affected cells. X-ray scans (see Figure 1) and final dissection of brood cells at the end of the exposure period revealed that brood mortality was exclusively linked to the presence of parasitoid wasp larvae in the respective cells $(N=33$, overall mortality of $28.9 \%)$. Parasitoid-induced mortality was significantly less frequent in coated $(17.5 \%)$ than in uncoated brood cells (40.4\%; Fishers Exact Test: $N=114$, two-tailed $p=$ 0.013; see Figure 3B). Unsheltered (and heavily mold infected) internodes exhibited significantly less parasitoid-induced mortality $(10 \%)$ than sheltered ones $(39.2 \%$; Fishers Exact Test: $N=$ 114 , two-tailed $p=0.001$ ). Parasitoid wasps hatching from the infected cells were identified as the chalcidoid Melittobia acasta (Eulophidae, courtesy Stefan Schmidt, ZSM Munich), a generalist parasitoid of solitary bees and wasps (Matthews et al., 2009). Brood cells parasitized by Melittobia showed small circular punctures in the wool wall, which demonstrates that Melittobia can burrow through dense layers of plant wool to reach the host larva.

\section{DISCUSSION}

The present study is the first to test functional hypotheses of megachilid bee nest building materials by experimenting with

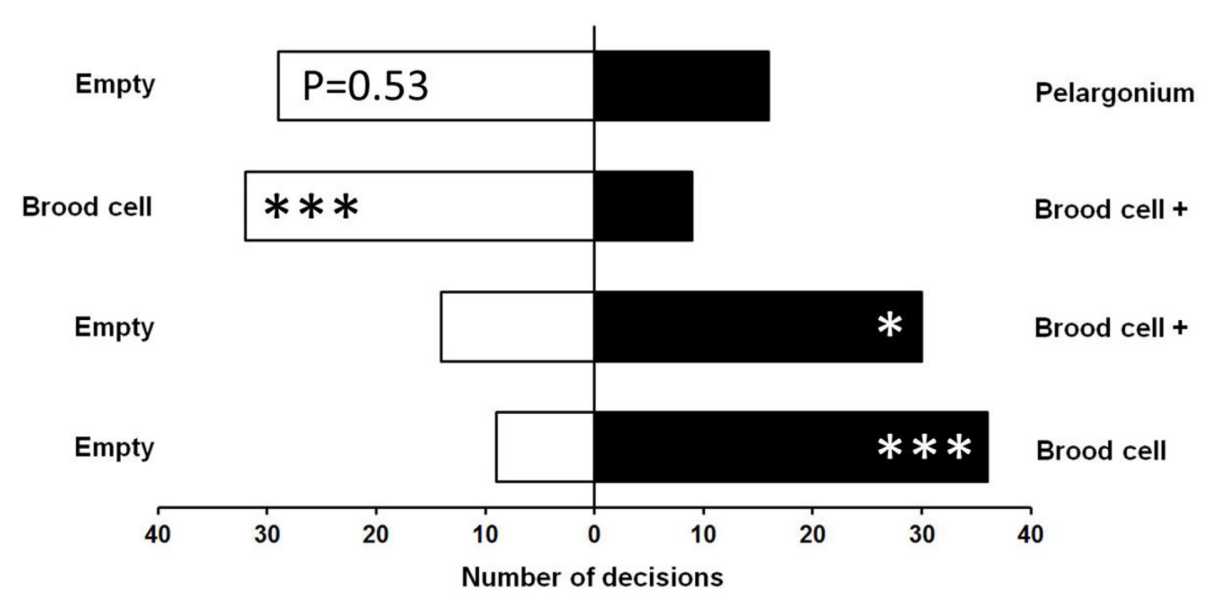

FIGURE 2 | Orientation of female parasitic wasps, Monodontomerus obscurus, toward olfactory stimuli of Anthidium manicatum brood cells with $(+)$ or without a coating of Pelargonium trichome secretion in a y-type olfactometer. Both coated and uncoated brood cells were preferred over an empty chamber. When coated and uncoated cells were offered in a dual choice situation, wasps preferred the uncoated cells. Samples of Pelargonium buds and petioles were tendentially avoided in comparison to an empty chamber (top). Goodness-of-fit $X^{2}$-Test: ${ }^{*} p<0.05$, ${ }^{* * *} p<0.001$. 

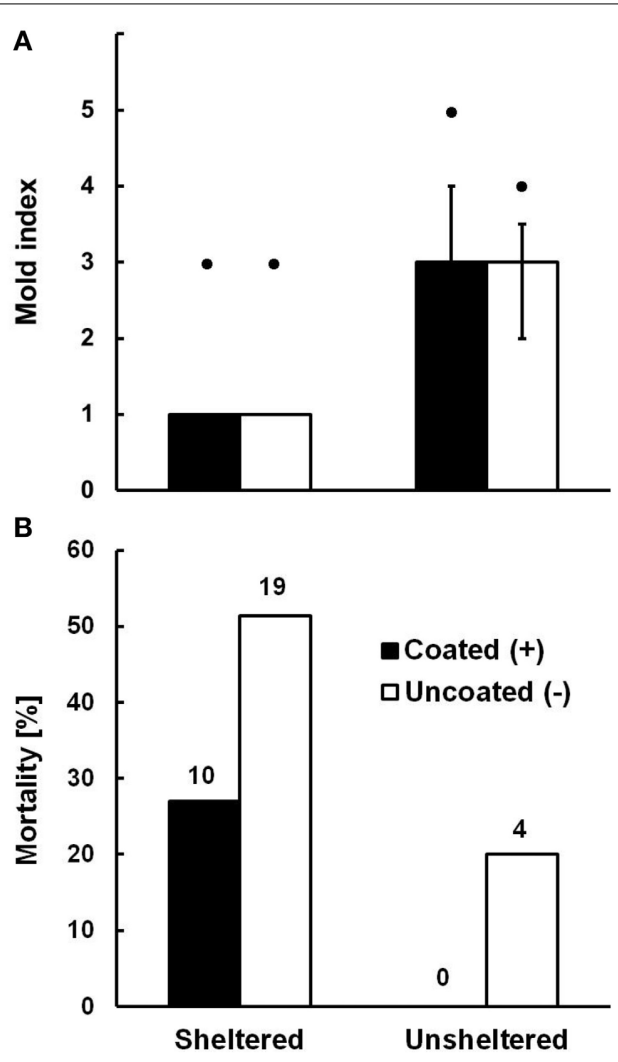

FIGURE 3 | (A) Mold growth (Median and quartile range of mold index) on Anthidium manicatum brood cells and (B) parasitoid wasp-induced mortality of larvae depending on whether the wool of their brood cells was coated with Pelargonium extrafloral tichome secretions or not, at sites sheltered or unsheltered from direct rainfall. Maximal mold category in the respective groups are indicated by black dots above columns in (A), and absolute numbers of parasitized brood are given above columns in (B). See text for statistics.

actual brood cells. Both olfactometer tests and field exposure assays consistently suggest that the coating of cells with extrafloral trichome secretion reduces chalcidoid wasp parasitism. No support was found for a protective effect against microbial (mold) decay, which had previously been believed to be the most likely function (Müller et al., 1996).

Parasitoids are a major cause of mortality in many insects (Godfray, 1994), including megachilid bees (Krunic et al., 2005), and parasitoid-mediated selection may plausibly have promoted the evolution of wool coating behaviors and associated morphological traits. Different mechanism may have been involved in generating the observed protective effects in our study. The olfactometer tests suggest that trichome secretions reduce the attractiveness of the odor of the host brood cell to parasitic wasps. However, as it is currently unknown whether the tested species of wasp, M. obscurus, does parasitize wool-carder bees in nature, the implications of this result for populations of A. manicatum remain unclear, and future tests should be carried out with M. acasta. In any case, the significant reduction in attractiveness demonstrates that the odor of the brood cells was altered by the trichome secretions. Chalcidoid wasps, including Melittobia spp., are known to locate their hosts by means of olfactory cues, emanating either from larvae, cocoons, larval provisions, or larval feces (Vet and Dicke, 1992; Silva-Torres et al., 2005; Cusumano et al., 2010; Filella et al., 2011), and a change in the respective odor may plausibly change host recognition. Pelargonium extrafloral trichome secretions contain anacardic acid derivatives as their main constituents (Gerhold et al., 1984), but also a range volatiles, especially sesquiterpenes (Eltz, pers. obs.). Both the sesquiterpenes as well as potential break-up products of anacardic acids may be responsible for the changed odor and reduced attractiveness of coated brood cells in dual choice tests. From our results we cannot clearly distinguish whether Pelargonium volatiles mask host recognition cues or whether they actively repel wasps. However, the fact that Monodontomerus wasps will neglect coated cells only when the other chamber presents a positive stimulus, e.g., an uncoated cell, but not when tested against an empty stimulus chamber, seems to favor the hypothesis of (incomplete) odor masking.

Reduced parasitism in field exposure tests may also involve non-olfactory mechanisms. Pelargonium trichome secretions are both sticky and mildly toxic to arthropods, thus mediating protection against phytophagous insects and mites in Pelargonium (Walters et al., 1989; Schultz et al., 2006). It is possible that the stickiness of trichome secretions makes it more difficult for chalcidoid wasps to burrow their way through the plant wool surrounding the host larva or cocoon. Parasitism experiments in the lab with artificially coated brood cells, e.g., using synthetic anacardic acids, should be carried out to elucidate the exact mechanisms of trichome secretion-based defense against parasitoids.

Clearly, our failure to prove a protective effect against mold does not generally preclude such a function. In our experiment brood was already at a late larval stage when exposed in the field, meaning that food provisions (pollen) had already been largely consumed by the larvae. An earlier exposure to moisture might have promoted the growth of mold on the hygroscopic pollen, and coating cells with trichome secretions could have conveyed a survival advantage to brood in that case. Interestingly, however, exposure to rainfall and extreme growth of mold on the brood cells did not result in increased mortality of larvae. In fact, the mortality of larvae was reduced in the cells exposed to rainfall (and mold) because these were more rarely parasitized by Melittobia wasps than unprotected cells. Although the reduced parasitation in exposed units may also be related to them being further away from other bee nests (being outside the nesting aggregation), it is an intriguing possibility that moisture/mold at the right time may even convey a survival advantage by providing parasitoid-free space to the developing brood. In any case, the silk cocoon which the larva spins within the the brood cell after having consumed its pollen provisions clearly provides formidable protection against both moisture and microbes. See Rozen et al. (2011) for how megachilid cocoon morphology promotes such a barrier function while at the same time allowing the influx of air (oxygen).

Our results have some implications regarding the causes of diversification within Megachilidae. Litman et al. (2011) demonstrated that major bursts in diversification rates and extant species 
numbers within the family are associated with alterations in nesting biology, especially with the origin of brood cell linings made from foreign (and often plant-derived) materials. These foreign materials were suggested to have a similar role as Dufour-gland derived cell linings in other families of bees (Cane, 1981; Hefetz, 1987; Mitra, 2013) and seem to have promoted the colonization of non-desert habitats in Megachilidae. Protection against spoilage of hygroscopic pollen against microbial decay was believed to be the major evolutionary advantage of the cell linings (Litman et al., 2011). Our results do not contradict this notion, but suggest that other benefits, i.e., protection against parasitoids, should also be taken into account. Protection against parasitoids may have become more important when megachilids shifted to nesting in cavities above ground, whereas ground-nesting relatives rely on plant-derived cell linings mostly for maintaining water balance of brood cells and/or for protection against microbes (Praz, pers. comm.). Parasitoids can be a powerful selective force that may also promote diversification in host taxa by pushing them into enemy-free space on novel resources (Feder, 1995; Leppanen et al., 2013). Such parasitoid-driven speciation is indicated in phytophagous insects that suffer different levels of parasitism on different host plants (Feder, 1995; Lill et al., 2002; Singer and Stireman, 2005). Similar to shifts in host plants in phytophagous insects, shifts in nest building materials could have promoted diversification in megachilid bees. Species isolation may even be a direct consequence of odor changes resulting from shifts in cell construction materials if bees mate at nests sites, which they often do (Paxton, 2005), and if males locate nest sites by olfactory cues.

\section{ACKNOWLEDGMENTS}

This work was supported by the Ruhr-University Bochum. We thank Manfred Reimann and the staff of the Botanical Garden of the Ruhr-University Bochum for providing space, plants, expertise, and logistic help with setting up the flight cages for Anthidium rearing.

\section{SUPPLEMENTARY MATERIAL}

The Supplementary Material for this article can be found online at: http://www.frontiersin.org/journal/10.3389/fevo.2014. 00086/abstract

\section{REFERENCES}

Cane, J. H. (1981). Dufours gland secretion in the cell linings of bees (Hymenoptera, Apoidea). J. Chem. Ecol. 7, 403-410. doi: 10.1007/BF00995762

Cane, J. H., Griswold, T., and Parker, F. D. (2007). Substrates and materials used for nesting by North American Osmia bees (Hymenoptera: Apiformes: Megachilidae). Ann. Entomol. Soc. Am. 100, 350-358. doi: 10.1603/00138746(2007)100[350:SAMUFN]2.0.CO;2

Cardinal, S., and Danforth, B. N. (2013). Bees diversified in the age of eudicots. Proc. R. Soc. B Biol. Sci. 280, 1-8. doi: 10.1098/rspb.2012.2686

Cusumano, A., Gonzalez, J. M., Colazza, S., and Vinson, S. B. (2010). Behavioral responses of the parasitoid Melittobia digitata to volatiles emitted by its natural and laboratory hosts. Entomol. Exp. Appl. 136, 301-307. doi: 10.1111/j.15707458.2010.01027.x

Dötterl, S., and Vereecken, N. J. (2010). The chemical ecology and evolution of bee-flower interactions: a review and perspectives. Can. J. Zool. 88, 668-697. doi: 10.1139/Z10-031

Duangphakdee, O., Koeniger, N., Deowanish, S., Hepburn, H. R., and Wongsiri, S. (2009). Ant repellent resins of honeybees and stingless bees. Insectes Soc. 56, 333-339. doi: 10.1007/s00040-009-0027-z
Eltz, T., Sager, A., and Lunau, K. (2005). Juggling with volatiles: exposure of perfumes by displaying male orchid bees. J. Comp. Physiol. A 191, 575-581. doi: 10.1007/s00359-005-0603-2

Feder, J. L. (1995). The effects of parasitoids on sympatric host races of Rhagoletis pomonella (Diptera, Tephritidae). Ecology 76, 801-813. doi: 10.2307/19 39346

Filella, I., Bosch, J., Llusia, J., Seco, R., and Penuelas, J. (2011). The role of frass and cocoon volatiles in host location by Monodontomerus aeneus, a parasitoid of Megachilid solitary bees. Environ. Entomol. 40, 126-131. doi: 10.1603/EN10165

Fliszkiewicz, M., Kusnierczak, A., and Szymas, B. (2012). The accompanying fauna of solitary bee Osmia bicornis (L.) syn. Osmia rufa (L.) nests settled in different biotopes. J. Apic. Sci. 56, 51-58. doi: 10.2478/v10289-012-0006-x

Gerhold, D. L., Craig, R., and Mumma, R. O. (1984). Analysis of trichome exudate from mite-resistant Geraniums. J. Chem. Ecol. 10, 713-722. doi: 10.1007/BF00988538

Godfray, H. C. J. (1994). Parasitoids: Behavioral and Evolutionary Ecology. Princeton, NJ, USA: Princeton University Press.

Gonzalez, V. H., and Griswold, T. L. (2013). Wool carder bees of the genus Anthidium in the Western Hemisphere (Hymenoptera: Megachilidae): diversity, host plant associations, phylogeny, and biogeography. Zool. J. Linn. Soc. 168, 221-425. doi: 10.1111/Zoj.12017

Grimaldi, D. (1999). The co-radiations of pollinating insects and angiosperms in the Cretaceous. Ann. Mo. Bot. Gard. 86, 373-406. doi: 10.2307/2666181

Hammer, Ø., Harper, D. A. T., and Ryan, P. D. (2001). PAST: Paleontological statistics software package for education and data analysis. Palaeontol. Electron. 4, 9.

Hefetz, A. (1987). The role of dufours gland secretions in bees. Physiol. Entomol. 12, 243-253. doi: 10.1111/j.1365-3032.1987.tb00749.x

Krunic, M., Stanisavljevic, L., Pinzauti, M., and Felicioli, A. (2005). The accompanying fauna of Osmia cornuta and Osmia rufa and effective measures of protection. Bull. Insectol. 58, 141-152.

Lampert, K. P., Pasternak, V., Brand, P., Tollrian, R., Leese, F., and Eltz, T. (2014). 'Late' male sperm precedence in polyandrous wool-carder bees and the evolution of male resource defence in Hymenoptera. Anim. Behav. 90, 211-217. doi: 10.1016/j.anbehav.2014.01.034

Leppanen, S. A., Altenhofer, E., Liston, A. D., and Nyman, T. (2013). Ecological versus phylogenetic determinants of trophic associations in a plant-leafminerparasitoid food web. Evolution 67, 1493-1502. doi: 10.1111/evo.12028

Lill, J. T., Marquis, R. J., and Ricklefs, R. E. (2002). Host plants influence parasitism of forest caterpillars. Nature 417, 170-173. doi: 10.1038/417170a

Litman, J. R., Danforth, B. N., Eardley, C. D., and Praz, C. J. (2011). Why do leafcutter bees cut leaves? New insights into the early evolution of bees. Proc. R. Soc. B Biol. Sci. 278, 3593-3600. doi: 10.1098/rspb.2011.0365

Matthews, R. W., Gonzalez, J. M., Matthews, J. R., and Deyrup, L. D. (2009). Biology of the parasitoid Melittobia (Hymenoptera: Eulophidae). Annu. Rev. Entomol. 54, 251-266. doi: 10.1146/annurev.ento.54.110807.090440

Messer, A. C. (1985). Fresh dipterocarp resins gathered by megachilid bees inhibit growth of pollen-associated fungi. Biotropica 17, 175-176. doi: 10.2307/2388512

Mitra, A. (2013). Function of the Dufour's gland in solitary and social Hymenoptera. J. Hymenoptera Res. 35, 33-58. doi: 10.3897/jhr.35.4783

Müller, A., Töpfl, W., and Amiet, F. (1996). Collection of extrafloral trichome secretions for nest wool impregnation in the solitary bee Anthidium manicatum. Naturwissenschaften 83, 230-232.

Paxton, R. J. (2005). Male mating behaviour and mating systems of bees: an overview. Apidologie 36, 145-156. doi: 10.1051/apido:2005007

Rank, G. H., and Goerzen, D. W. (1981). Native Leafcutter Bee species and associated parasites in commercial hives in Saskatchewan, Canada. Apidologie 12, 211-220. doi: 10.1051/apido:19810301

Rozen, J. G., Rozen, J. R., and Hall, H. G. (2011). Gas diffusion rates through cocoon walls of two bee species (Hymenoptera: Megachilidae). Ann. Entomol. Soc. Am. 104, 1349-1354. doi: 10.1603/AN11050

Schultz, D. J., Olsen, C., Cobbs, G. A., Stolowich, N. J., and Parrott, M. M. (2006). Bioactivity of anacardic acid against Colorado potato beetle (Leptinotarsa decemlineata) larvae. J. Agric. Food Chem. 54, 7522-7529. doi: 10.1021/jf061481u

Silva-Torres, C. S. A., Matthews, R. W., Ruberson, J. R., and Lewis, W. J. (2005). Olfactory cues in host finding by Melittobia digitata (Hymenoptera: Eulophidae). Ann. Entomol. Soc. Am. 98, 595-600. doi: 10.1603/00138746(2005)098[0595:OCIHFB]2.0.CO;2 
Singer, M. S., and Stireman, J. O. (2005). The tri-trophic niche concept and adaptive radiation of phytophagous insects. Ecol. Lett. 8, 1247-1255. doi: 10.1111/j.14610248.2005.00835.x

Vet, L. E. M., and Dicke, M. (1992). Ecology of infochemical use by natural enemies in a tritrophic context. Annu. Rev. Entomol. 37, 141-172. doi: 10.1146/annurev.en.37.010192.001041

Walters, D. S., Grossman, H., Craig, R., and Mumma, R. O. (1989). Geranium defensive agents. 4. Chemical and morphological bases of resistance. J. Chem. Ecol. 15, 357-372. doi: 10.1007/BF02027796

Westrich, P. (1989). Die Wildbienen Baden-Würtembergs: Allgemeiner Teil. Stuttgart, Germany: Eugen Ulmer GmbH \& Co.

Conflict of Interest Statement: The authors declare that the research was conducted in the absence of any commercial or financial relationships that could be construed as a potential conflict of interest.
Received: 05 November 2014; accepted: 12 December 2014; published online: 06 January 2015.

Citation: Eltz T, Küttner J, Lunau K and Tollrian R (2015) Plant secretions prevent wasp parasitism in nests of wool-carder bees, with implications for the diversification of nesting materials in Megachilidae. Front. Ecol. Evol. 2:86. doi: 10.3389/fevo. 2014.00086

This article was submitted to Chemical Ecology, a section of the journal Frontiers in Ecology and Evolution.

Copyright (C) 2015 Eltz, Küttner, Lunau and Tollrian. This is an open-access article distributed under the terms of the Creative Commons Attribution License (CC BY). The use, distribution or reproduction in other forums is permitted, provided the original author(s) or licensor are credited and that the original publication in this journal is cited, in accordance with accepted academic practice. No use, distribution or reproduction is permitted which does not comply with these terms. 